\title{
Degradable Polyhydroxyalkanoates \\ of Microbial Origin as a Technical Analog \\ of Non-Degradable Polyolefines
}

Tatiana G. Volova*

Institute of Biophysics SB RAS 50/50 Akademgorodok, Krasnoyarsk, 660036, Russia

Siberian Federal University

79 Svobodny, Krasnoyarsk, 660041, Russia

Received 19.01.2015, received in revised form 16.03.2015, accepted 21.05.2015

The paper considers problems concerning accumulation of synthetic plastic wastes in the biosphere. A set of data is presented on materials of new generation - polymers of natural origin (bioplastics) which can degrade in the environment to harmless products. Biotechnologically synthesized biodegradable microbial polyhydroxyalkanoates and mechanisms of their degradability are characterized.

Keywords: synthetic polymers, biopolymers, polyhydroxyalkanoates, PHA, degradability.

DOI: $10.17516 / 1997-1389-2015-8-2-131-151$.

\section{Разрушаемые микробные полигидроксиалканоаты \\ в качестве технического аналога \\ неразрушаемых полиолефинов}

Т.Г. Волова

Институт биофизики СО РАН

Россия, 660036, Красноярск, Академгородок, 50/50

Сибирский федеральный университет

Россия, 660041, Красноярск, пр. Свободныгй, 79

В статье рассмотрены проблемы, связанные с накоплением в биосфере отходов синтетических пластиков. Представлен массив данных по материалам нового поколения - биопластикам -

(C) Siberian Federal University. All rights reserved

* Corresponding author E-mail address: volova45@mail.ru 
полимерам природного происхождения, способным разрушаться в окружающей среде до безвредных продуктов. Охарактеризован класс микробных полигидроксиалканоаты (ПГА) биоразрушаемых полимеров, синтезируемых биотехнологическим способом, и механизм их разрушаемости.

Ключевые слова: синтетические полимеры, биополимеры, полигидроксиалканоаты, ПГА, разрушаемость.

\section{Введение}

Концепция устойчивого развития, являющаяся ключевой задачей XXI века, предполагает ведение новых форм хозяйствования, которые обеспечат сокращение темпов потребления невозобновляемых ископаемых видов сырья, сохранив их для будущих поколений, более эффективное использование энергоресурсов, переход на новые функциональные и экологически чистые материалы, подлежащие рециклингу, а также освоение принципиально новых средств и технологий для защиты окружающей среды и рационального природопользования.

Охрана окружающей среды - неотъемлемый компонент устойчивого развития. В результате активной хозяйственной деятельности в настоящее время под угрозой находятся биотические и абиотические компоненты окружающей среды. На фоне роста населения планеты во все более широком масштабе возрастает производство и потребление химических веществ. В связи с этим неуклонно увеличивается количество проблем, связанных с охраной окружающей среды. Несмотря на все усилия по предотвращению накопления отходов и содействию их рециркуляции, масштабы ущерба, причиняемого окружающей среде в результате чрезмерного потребления, количество образующихся отходов и степень неустойчивого природопользования возрастают. Это диктует необходимость разработки новых и эффективных технологий и средств, не наносящих вреда окружающей среде, т. е. «дружественных» природе.

Загрязнение планеты отходами наряду с интенсивным потреблением природных ресурсов ведет к разрушению механизма саморегулирования биосферы с непредсказуемыми последствиями. Академик Н.Н. Моисеев в конце 70-х годов прошлого века писал: «Главной проблемой глобальной экологии является устойчивость биосферы, нарушение ее устойчивости практически означает ликвидацию человечества на планете Земля». Загрязнение окружающей среды во многих регионах достигло критического предела. Глобальной экологической проблемой стало повсеместное применение неразрушаемых синтетических пластиков, аккумулируемых в природной среде, что наносит огромный ущерб биосфере. Необходим переход на новые безвредные для природы технологии и средства.

Природные полимеры, синтезируемые микро- и макроорганизмами, подвержены деструкции и разлагаются в окружающей среде, вовлекаясь в круговорот. В этих процессах ключевую роль играют микроорганизмы, которые способны ассимилировать разнообразные органические соединения, обеспечивая самоочищение окружающей среды от загрязняющих веществ. Замена синтетических полимеров природными - 
один из путей снижения антропогенного давления на окружающую среду.

Развитие науки и техники приводит к все более широкому внедрению в практику целевых продуктов, синтезируемых микроорганизмами. Ценным продуктом биотехнологии являются микробные полигидроксиалканоаты (ПГА) - полимеры гидроксипроизводных жирных кислот (т.н. биопластики), которые обладают спектром полезных свойств, включая биосовместимость и биоразрушаемость. ПГА перспективны для различных сфер применения - от изделий биомедицинского назначения до разрушаемой упаковки пищи и препаратов для коммунального и сельского хозяйства (Sudech, Doi, 2000; Stock et al., 2000; Asrar, Gruys, 2002; Volova, 2004; Volova et al., 2013; Прудникова, Волова, 2012). Наблюдаемое сегодня наращивание объемов выпуска и расширение сфер применения ПГА делают необходимым изучение способности окружающей среды к самоочищению от этого вида биологической продукции. Однако количество работ, в которых были бы комплексно исследованы различные аспекты процесса разрушения ПГА в природной среде, в целом невелико; большинство исследований выполнено в лабораторных условиях без учета всей сложности этого процесса. Вместе с тем разрушаемость ПГА зависит от многих составляющих, включая собственно химический состав и структуру полимера, микробную составляющую биоты как главного агента их биодеградации, а также условий среды, которые, в свою очередь, определяются биологическими, гидрохимическими, климатическими и погодными условиями. Поэтому только комплексные исследования позволяют адекватно и корректно исследовать этот многофакторный процесс.

\section{Синтетические пластики - глобальная экологическая проблема}

Синтетические полимерные материалы стали неотъемлемой частью современной жизни, однако их применение создает ряд проблем. Синтетические полимеры получают из невозобновляемых ресурсов, и их накопление ведет к загрязнению окружающей среды и создает глобальную экологическую проблему. Объемы выпуска синтетических пластмасс, главным образом полиолефинов (полиэтилена и полипропилена), получаемых в процессах нефтеоргсинтеза, огромны и к настоящему моменту превысили 300 млн т в год. Нельзя не отметить при этом, что до 98 \% мирового объема полимерных материалов производится из невозобновляемого ископаемого сырья - нефти, газа, продуктов переработки угля, запасы которых истощаются. Полимеры из нефти тоже могут рассматриваться как возобновляемые, но пройдет более миллиона лет для превращения биомассы в новые ископаемые источники топлива, которые используются в качестве сырья в производстве пластика. Поскольку уровень потребления пластиков намного выше уровня восполнения ископаемых углеродсодержащих ресурсов, большой дисбаланс существует в «углеродном цикле».

Сегодня области применения пластмасс широки и включают практически все сферы человеческой деятельности. Самым крупным направлением переработки пластмасс является производство тары и упаковки. Удельный вес этого сегмента в объеме потребления пластмасс составляет около $60 \%$ от объемов выпуска; до 40 \% «упаковочного» пластика расходуется для затаривания продуктов питания и розлива напитков. Основная часть изделий из синтетических пластиков скапливается на свалках, так как повторной переработке в развитых странах подвергается не более 
16-20 \% (Scott, 2002; Потапов, Пармон, 2010). Под полигоны и свалки твердых бытовых отходов, в которых доля синтетических материалов уже приближается к 60-70 \%, ежегодно отчуждается до 10 тыс. га земель, в том числе и плодородных, изымаемых из сельскохозяйственного оборота. Полиэтиленовый мусор захламляет территории городов, выводит из строя канализационные и дренажные системы. По данным Green Peace, ежегодно в воды Мирового океана попадает до $10 \%$ от объемов выпускаемых пластиков (Moore, 2001).

Океан, аккумулирующий загрязнения всех воздушных и речных потоков, служит конечным пунктом аккумуляции отходов. В Мировом океане образовались «острова», преимущественно состоящие из полиэтиленового и пластикового мусора. На данный момент известны пять больших скоплений мусорных пятен - по два в Тихом и Атлантическом океанах и одно - в Индийском океане. Данные мусорные круговороты в основном состоят из пластиковых отходов, образующихся в результате сбросов из густонаселённых прибрежных зон континентов (Зайцев, 2006; Markina, Aizdaicher, 2005). Один из них достиг размеров Америки. Гигантский «полимерный остров» начинается примерно в 500 милях от побережья Калифорнии, тянется через северную часть Тихого океана мимо Гавайских островов и приближается к берегам Японии. Около 100 млн т плавучего мусора занимают площадь, вдвое превышающую континентальную часть США; за 40 лет наблюдения его масса возросла в 100 раз. «Остров» имеет ряд неофициальных названий: «Великий тихоокеанский мусорный остров» (Great Pacific Garbage Patch), «Bocточный мусорный остров» (Eastern Garbage Patch), «Тихоокеанский мусороворот» (Рacific Trash Vortex) и пр. В 2001 г. масса пластика в нем превышала массу зоопланктона в зоне острова в шесть раз. Приблизительные оценки площади варьируются от 700 тыс. до 15 млн км ${ }^{2}$ и более (от 0,41 до $8,1 \%$ общей площади Тихого океана).

По мере увеличения степени загрязнения Мирового океана возрастает опасность не только снижения разнообразия живых организмов в природных водах - критическая загрязненность может привести к катастрофическим последствиям, при этом продукты моря употреблять в пищу скоро будет небезопасно. Пластиковые отбросы в Тихом океане являются причиной гибели более миллиона морских птиц в год, а также более 100 тыс. особей морских млекопитающих.

Возможные пути сокращения гигантских отходов синтетических пластиков - это утилизация, которую можно разделить на ряд главных направлений: сжигание, пиролиз, рециклизация и переработка. Однако как сжигание, так и пиролиз пластмассовых отходов кардинально не улучшают экологическую обстановку. Более того, сжигание - это дорогостоящий процесс, к тому же еще и приводящий к образованию высокотоксичных, а также супертоксичных (фураны и диоксины) соединений. Захоронение пластмассовых отходов это перекладывание сегодняшних проблем на плечи будущих поколений (Фомин, Гузеев, 2001; Kijchavengkul, Auras, 2008).

Повторная переработка пластмасс в определенной степени решает данный вопрос, но требует значительных трудовых и энергетических затрат, так как для этого необходимы следующие действия: отбор из бытового мусора пластической тары и упаковки, разделение собранных отходов по виду пластиков, мойка, сушка, измельчение и только затем переработка в новое полимерное изделие. Необходимость проведения мероприятий для рециклизации пластмассовых отходов, в особенности из тары и упаковки, в ряде стран 
закреплена законодательно. В странах ЕС законодательные инициативы и акты обязывают производителей пластмассовой упаковки использовать при этом до 15 \% в качестве сырья вторичные пластмассы. Связано это с тем, что захоронение и сжигание не решают вопросов рецикла многомиллионных синтетических отходов и их аккумуляция в биосфере - глобальная экологическая проблема. Рассматриваемые проекты как захоронения и компостирования, так и возможной реутилизации химических пластиков не оптимистичны. Полагают, что это технически невозможно, так как только для транспортных и непищевых упаковок возможно применение до 25 \% вторичных пластмасс, но не для пищевых продуктов. Нельзя не отметить, что сбор и повторная переработка полимерной тары и упаковки неизменно приводят к ее удорожанию, а качество рециклизованного полимера и изделий при этом снижается. Если предположить, что значительная часть тары и упаковки будет использоваться повторно, то для этого необходимо ответить на вопросы, какая кратность переработки допустима, и когда неизбежно наступит время для захоронения или уничтожения пластика (Потапов, Пармон, 2010).

Основными компонентами трансформации и утилизации отходов антропогенного и природного происхождения являются микроорганизмы. Обладая мощным биохимическим потенциалом, они трансформируют более $90 \%$ органических субстратов, попадающих в почву и водоемы, обеспечивая биосферные круговороты. Однако ввиду того что синтетические полимеры, по словам академика И.И. Гительзона, «не имеют в природе своего потребителя», их деструкция в окружающей среде становится весьма проблематичной.

Применение синтетических полимерных материалов из нефти и ее производных - это не только глобальная экологическая проблема и возрастание расходов на их утилизацию, но и обоснованное беспокойство в связи с негативным влиянием на здоровье населения. Сравнительно недавно установлено, что ряд материалов, используемых, в частности, для производства пластиковых контейнеров, могут стать причиной возникновения серьезных заболеваний, включая онкологические. Это связано с использованием бисфенола А при изготовлении синтетической упаковки. Согласно приблизительным подсчетам, каждый год во всем мире для упаковки пищевых продуктов и напитков производится 2,8 млн т бисфенола. По степени воздействия на организм, бисфенол А относят к умеренно опасным веществам. Бисфенол А способен растворяться в воде, а значит, попадает в продукты питания и хорошо всасывается в кровь, негативно воздействуя на человека.

Выход из этого глобального экологического «тупика» - в постепенном переходе на новые типы материалов, безопасные для природы и биоты. В последние годы все более актуальными становятся работы по биополимерам (полимерам биологического происхождения). Главной целью данного направления служит поиск и изучение новых биополимеров и получение фундаментальной основы для конструирования биологических систем, синтезирующих полимеры с заданными свойствами, а также разработки технологий их применения.

\section{Эколого-биотехнологические} альтернативы

\section{продуктам химического синтеза}

Многообразие форм живой материи и новые знания в области физики и химии живых систем позволяют конструировать биологические системы различной степени сложности и организации для синтеза широчайшего 
спектра макромолекул. Микроорганизмы и технологии с их использованием являются источником для получения разнообразных ценных продуктов пищевого, кормового, медицинского и технического назначения, включая новые экологически чистые материалы. Переход на новые типы материалов, которые разрушаются в природной среде естественным путем до безвредных продуктов, становится насущной проблемой. Полимеры, получаемые из природного сырья или синтезируемые микроорганизмами (так называемые биополимеры, или биопластики), в отличие от нефтепродуктов, практически не вносят вклад в пополнение парниковых газов и глобальное потепление. Одно из преимуществ использования биоразлагаемых полимеров на биологической основе - возможность помочь обновить «углеродный цикл», или «реинкарнацию углерода». В отношении альтернативных пластиков на основе масличных культур экономия выбросов парниковых газов в эквиваленте $\mathrm{CO}_{2}$ оценивается в размере 1,5 т на 1 т полиола, изготовленного из рапсового масла (Kijchavengkul, Auras, 2008). Национальный институт стандартов (NIST) оценил материально-производственные запасы и «жизненные» циклы двух новых полиолов, получаемых на основе бобовых. Полиолы на соевой основе практически в 4 раза снижают экологический неблагоприятный эффект по сравнению с полиолами нефтехимического происхождения. В перспективе биоразлагаемые полимеры обладают значительными возможностями для извлечения прибыли, сокращая отходы мусорных свалок, куда сегодня свозится до 80 \% пластиковых отходов, благодаря переходу на производство полностью возобновляемых ресурсов в форме энергии или удобрений, которые в дальнейшем также могут быть переработаны в земле и промышленных установках, закрывая тем самым углеродный цикл. По данным европейских исследований, полимеры на основе крахмала обеспечивают экономию энергии и выбросов от 12 до 40 Дж и 0,8-3,2 т выбросов $\mathrm{CO}_{2}$ на каждую тонну пластика в сравнении с 1 т синтетического полиэтилена. Страны, развивающие это направление, автоматически освобождаются от квот на выбросы, налагаемых Киотским протоколом. Так, Евросоюз брал на себя обязательства с 2008 по 2012 г. сократить объем выбросов $\mathrm{CO}_{2}$ в атмосферу на 8 \% относительно уровня 1990 г.; Япония обязуется сократить такие выбросы на $6 \%$.

В 2000 г. ЕС принял стандарт EN 13432, регламентирующий требования к биоразлагаемым полимерам. По решению Европейской комиссии № 2001/524/WE он приведен в соответствие с директивой № 94/62/WE. Стандарт внедряет критерии оценки и процедуры, касающиеся возможности естественного гниения биоразлагаемых синтетических материалов в компостных ямах, а также их обработку без присутствия кислорода (т. е. рециклинг органических веществ, а не сжигание).

На рис. 1 показан путь трансформации полимеров компостированием, хотя практически и теоретически полимеры на биологической основе могут быть переработаны и далее использованы нормальными путями без специальной переработки.

Путь от урожая через получение, использование к переработке полимеров тем или иным способом можно образно назвать «от колыбели к могиле». Если продукт либо упаковка компостируются, образуется гумус и диоксид углерода. Диоксид углерода используется растениями в ходе фотосинтеза, а гумус возвращается в землю в качестве удобрений для получения питательных веществ, потребляемых растениями (рис. 2).

Цикл процессов от сбора урожая до возвращения продуктов преобразования био- 


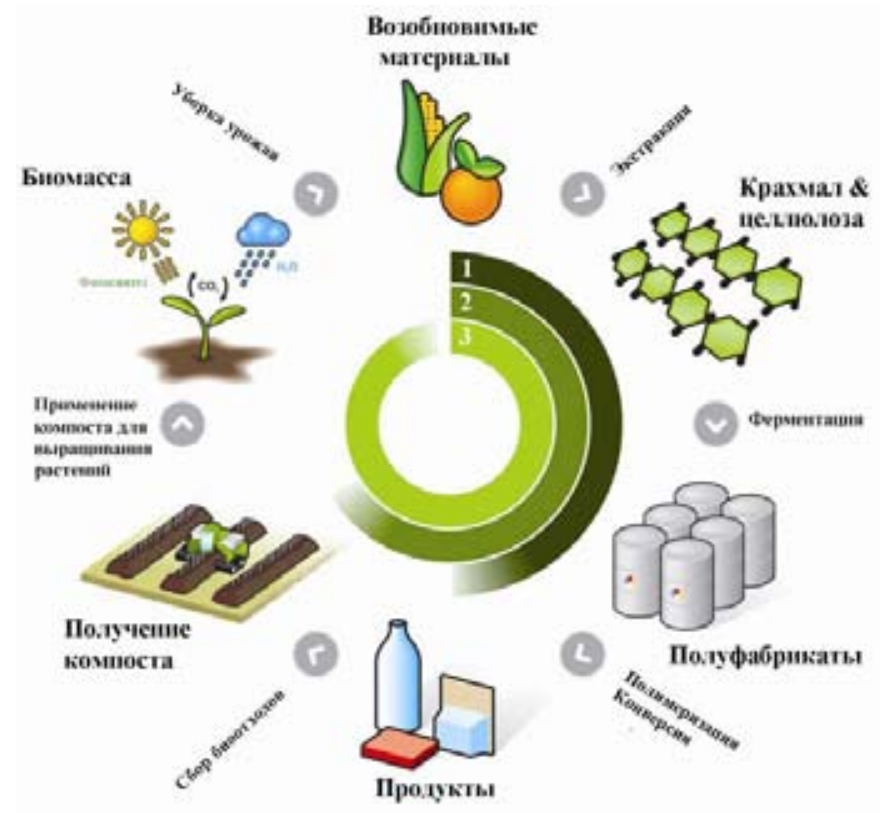

Рис. 1. Схема производства, потребления и утилизации полимеров, полученных из возобновляемых источников, включающая стадию компостирования: 1 - путь от сбора урожая до получения продукта; 2 - путь от сбора урожая до утилизации биополимеров; 3 - путь от сбора урожая до сбора урожая (Kijchavengkul, Auras, 2008)

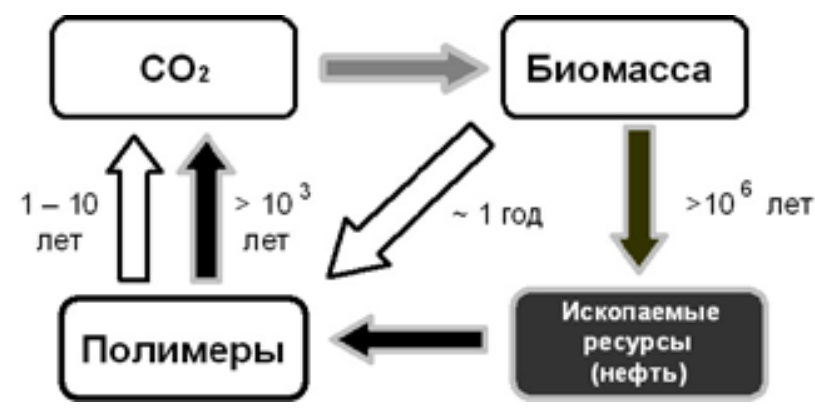

Рис. 2. Цикл углерода полимеров, полученных из нефти, и биополимеров. Путь возобновляемых ресурсов (белые стрелки); путь ископаемых (невозобновляемых) ресурсов (черные стрелки); путь возобновляемых и невозобновляемых ресурсов (серая стрелка) (Kijchavengkul, Auras, 2008)

полимеров в землю для выращивания новой биомассы и до следующего сбора урожая относится к процессу «от колыбели к колыбели». Обычно после использования пластики, полученные из нефти, особенно пластики, используемые в упаковке и сельском хозяйстве, содержат примеси, снижающие возможность повторного использования. Таким образом, они заканчивают существование на мусор- ных свалках, где влага и кислород присутствуют в небольшом количестве либо совсем отсутствуют. На мусорной свалке даже биоразлагаемые материалы разлагаются крайне медленно. Напротив, биоразрушаемые биопластики нового поколения под воздействием почвенных и водных микроорганизмов трансформируются до гумуса и далее - до диоксида углерода и воды (конечных продук- 
тов распада органики) - в срок от нескольких месяцев до десятков суток в ходе компостирования. Сроки, необходимые для разложения тароупаковочных материалов в естественных условиях, могут составлять многие годы и десятилетия. Разложение в природной среде синтетических полимерных материалов осуществляется десятки и сотни лет, в то время как использование биополимеров приводит к значительному сокращению этих сроков. Скорость разложения материалов зависит от ряда факторов - вида полимера, влажности, температуры, светового воздействия, микробной составляющей среды и др. Наиболее высокой способностью к биодеструкции обладают полимеры, которые содержат химические связи, легко подвергаемые гидролизу. Процессы биологической деструкции биопластиков могут протекать в аэробных условиях с образованием диоксида углерода и воды, а также в аноксигенной среде, без участия кислорода, с образованием метана и воды.

Оценка сложившейся ситуации по разработке и освоению биодеградируемых пластиков позволяет выделить три основных направления в этой области: 1) получение пластмасс на основе воспроизводимых природных полимеров; 2) придание биоразлагаемости широко используемым в настоящее время высокомолекулярным синтетическим материалам; 3) синтез биоразрушаемых полиэфиров химическим или биотехнологическим способом.

Получение биопластмасс на основе природных биоразлагаемых полимеров типа крахмала, целлюлозы, хитозана или протеинов представляет собой, как правило, создание композиционных материалов с различными добавками. Компостируемые материалы, получаемые из смеси растительных и натуральных исходных продуктов, где основным компонентом является целлюлоза или ее производные, широко применяются в настоящее время в качестве исходного сырья для изготовления одноразовых изделий, упаковки и предметов первой необходимости.

Второе направление ориентировано на придание свойства биоразрушаемости синтетическим полимерам, выпускаемым в огромных количествах. Для этого в структуру пластиков можно вводить молекулы, содержащие в своем составе функциональные группы, способствующие ускоренному фоторазложению полимера, получать композиции с биоразлагаемыми природными добавками, способными в определенной степени инициировать распад основного полимера, а также направленно синтезировать биодеградируемые пластические массы на основе промышленно освоенных синтетических продуктов. Для ускорения фото- и биоразложения полиэтилена, полипропилена или полиэтилентерефталата в них вводят пульпу целлюлозы, алкилкетоны или фрагменты, содержащие карбонильные группы. Такие пленки сохраняются в течение 8-12 недель, прежде чем начнут фото- и биоразлагаться.

Третье направление получения разрушаемых биопластиков ориентировано на производство полимеров на основе гидроксикарбоновых кислот как химическим, так и биотехнологическим синтезом. Анализ литературных источников по разработке биоразлагаемых полимеров за последние годы указывает на активное развитие этого нового направления. Полиэфиры на основе гидроксикарбоновых кислот (гликолевой, молочной, валериановой, масляной) разлагаются в природной среде под воздействием экзодеполимераз почвенной и водной микрофлоры, так как являются для нее субстратом роста. Для получения полиэфиров этих кислот используются их димерные производные - гликолиды, лактиды в случае гликолевой и молочной 
кислот, либо $\beta$-, $\gamma$ - или $\varepsilon$-лактоны для остальных указанных кислот. Важной особенностью данных полимеров и изделий из них служит их высокая биосовместимость и подверженность биодеградации через механизм биодеструкции макромолекулярной цепи, причем конечными продуктами распада полимеров во многих случаях выступают безопасные для организма продукты, в том числе углекислый газ и вода. При развитии технологии их производства и удешевлении этих полимеров можно ожидать, что они могут стать перспективными для создания разрушающихся во внешней среде упаковочных материалов и других изделий, которые должны разрушаться по истечении срока эксплуатации.

Анализ литературы свидетельствует также о бурном росте интереса к выпуску разрушаемых биопластиков. Если в 2000 г. объемы их выпуска составляли лишь 2 тыс. т, то в 2006 г. они достигли 50 тыс. т, а к 2010 г. 200 тыс. т. В опубликованном докладе Института перспективных технологических исследований Еврокомиссии о разлагаемых полимерах на биологической основе говорится, что к 2010 г. на долю этих материалов будет приходиться 1-2 \% европейского рынка полимеров, а к 2020 г. - до 5 \%. Конструирование биополимеров за последние 10-15 лет превратилось в одно из основных междисциплинарных исследований. Главные цели данного направления работ: 1) поиск и изучение новых биополимеров; 2) получение фундаментальной основы для конструирования биологических систем, синтезирующих полимеры с заданными свойствами.

Одним из самых перспективных биодеградируемых пластиков для применения в упаковке в настоящее время является полилактид - продукт конденсации молочной кислоты. Это обусловлено прежде всего тем, что получение лактида и полилактида возможно как синтетическим способом, так и ферментативным брожением декстрозы сахара или мальтозы, сусла зерна или картофеля. Полилактид в компосте биоразлагается в течение одного месяца, усваивается он также микроорганизмами морской воды. При соответствующей пластификации полилактид становится эластичным и имитирует полиэтилен, пластифицированный поливинилхлорид или полипропилен. Срок службы полимера увеличивается с уменьшением мономера в его составе, а также после ориентации, которая повышает прочность, модуль упругости и термостабильность. Несмотря на все перечисленные достоинства полилактида, широкое внедрение его как полимера бытового и технического назначения до последнего времени сдерживается небольшими объемами выпуска, низкой производительностью технологических линий и, как следствие, высокой стоимостью продукции. В связи с этим вопросам удешевления получаемой биоразлагаемой продукции уделяется значительное внимание.

Наряду с полилактидами и полигликолидами из полиэфиров, способных к биоразложению, значимое место занимают полимеры гидроксипроизводных жирных кислот микробиологического происхождения, так называемые полигидроксиалканоаты(ПГА). Интерес к ПГА растет с конца 1980-х гг. Это новый класс природных полиэфиров, которые не подвержены быстрому небиологическому гидролизу, при этом их свойства (молекулярный вес, кристалличность, механическая прочность и разрушаемость) могут существенно варьировать. ПГА перспективны для применения в пищевой промышленности (упаковочный материал), сельском хозяйстве (обволакиватели семян, удобрений, пестицидов, разрушаемые пленки, тара для тепличных хозяйств) и других сферах, включая медицину и фармаколо- 
гию. С расширением сфер применения ПГА возникает необходимость изучения способности окружающей среды к самоочищению от данного вида биологической продукции, для этого необходимы комплексные исследования последствий взаимодействия ПГА с микробиоценозами различной структуры с учетом климатических и погодных условий среды и свойств собственно биоматериала.

\section{Полигидроксиалканоаты \\ и процесс их разрушаемости}

Расширение масштабов производства и сфер применения ПГА делают необходимым изучение последствий их применения, прежде всего процессов их биоразрушения в окружающей среде. Большинство исследований по разрушению ПГА выполнено в лабораторных условиях, при этом значительная часть посвящена изучению механизма взаимодействия надмолекулярной структуры ПГА с ПГА-деполимеризующими ферментами, структуре и молекулярной организации ПГАдеполимераз разных типов (Kim et al., 2007), а также описанию микроорганизмов, обладающих внеклеточными ПГА-деполимеразами.

ПГА разрушаются в биологических средах с образованием безвредных для окружающей среды продуктов: диоксида углерода и воды в аэробных условиях и метана и воды - в анаэробных. Биодеградация ПГА осуществляется специализированными ПГА-деградирующими микроорганизмами, обладающими внутри- или внеклеточными ПГА-деполимеразами (Jendrossek, Handrick, 2002). К настоящему времени идентифицировано 600 ПГА-деполимераз из различных микроорганизмов, которые на основе сравнения аминокислотных последовательностей объединены в 8 суперсемейств с 38 семействами (Knoll et al., 2009). Один штамм может содержать несколько генов, кодирую- щих ПГА-деполимеразы с различной специфичностью.

ПГА в биологических средах разрушаются в результате внутриклеточной деградации при участии эндодеполимераз. Полагают, что внутриклеточные деполимеразы не гидролизуют полукристаллические полимеры, выделенные из биомассы, а внеклеточные деполимеразы не обладают субстратной специфичностью по отношению к внутриклеточному полимеру, ассоциированному в гранулах внутри клеток. Это связано с тем, что внутриклеточный и выделенный из клетки ПГА находится в двух различных состояниях. Во внутриклеточных (нативных) гранулах высокомолекулярный полимер находится в подвижном аморфном состоянии (это беспорядочно расположенные и высоко подвижные цепи); при этом поверхностный слой гранулы состоит из протеинов и фосфолипидов (рис. 3) (Jendrossek, 2001).

В ходе экстракции из клетки поверхностный слой гранул полимера повреждается и полиэфирные цепи начинают кристаллизоваться. Внеклеточный ПЗГБ является частично кристаллическим полимером с аморфной фракцией, которая характеризуется той же самой температурой стеклования, что и внутриклеточный полимер (около $0{ }^{\circ} \mathrm{C}$ ), и кристаллической фракцией с температурой плавления около 170-180 ${ }^{\circ} \mathrm{C}$ (Scandola et al., 1992). Полимер полукристаллической структуры недоступен для атаки внутриклеточными деполимеразами. Путь внутриклеточной деградации включает у одних микроорганизмов гидролиз эфирных связей полимера ПГА-деполимеразой (гидролазой) до тетра-, три-, ди- и мономеров $\beta$-гидроксимасляной кислоты, у других - сразу до мономеров. Мономеры под воздействием НАД-зависимой $\beta$-3-гидроксибутиратдегидрогеназы превращаются в ацетоацетат, который в трансфераз- 


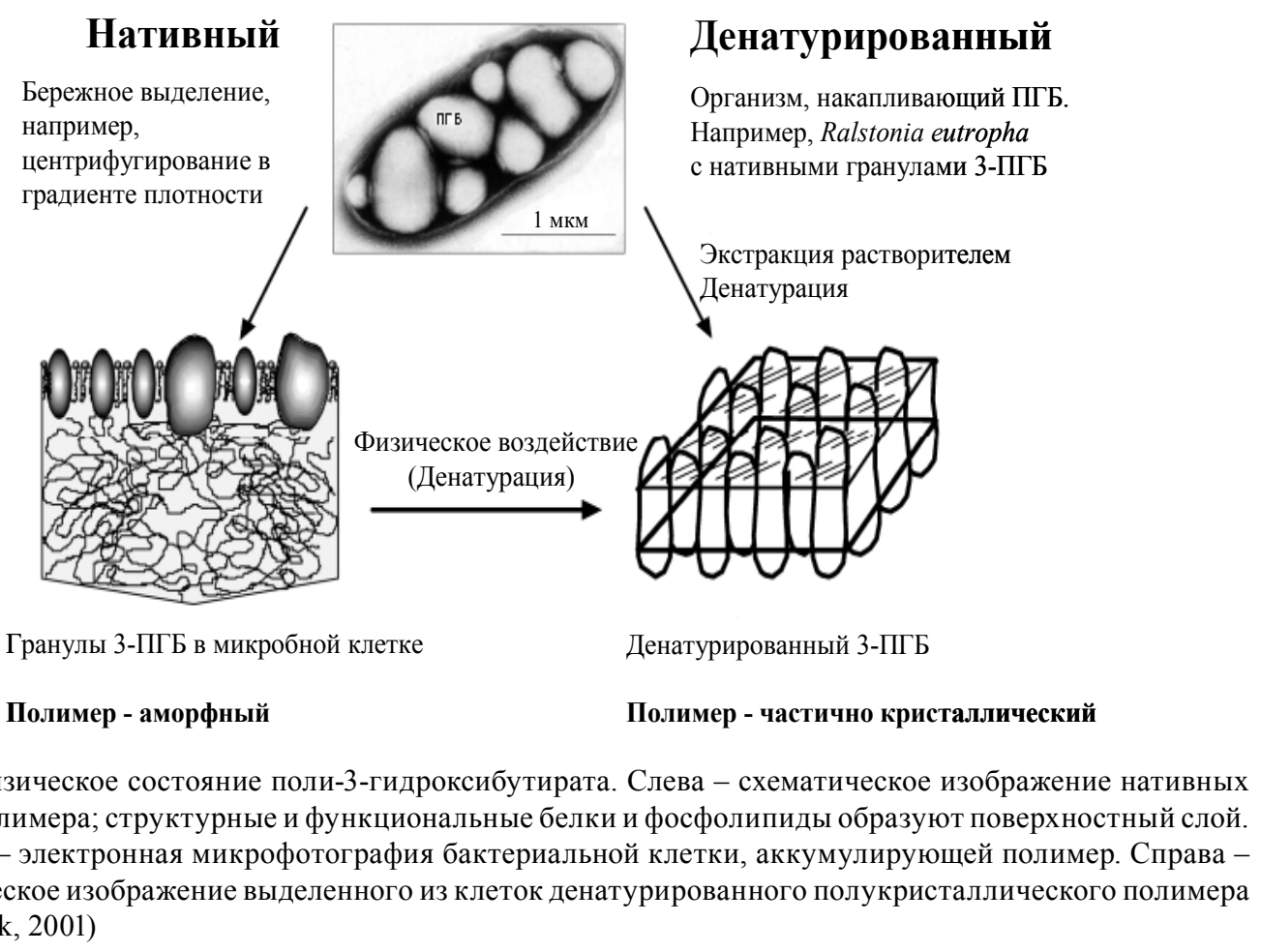

ной реакции конвертирует в ацетоацетил-КоА,

За последние два десятилетия охаракявляющийся субстратом для кетотиалазы, трансформирующей его в ацетил-КоА. Последний утилизируется внутриклеточно в системах метаболизма.

Способность деградировать внеклеточные ПГА зависит от активности и типа ПГАдеполимераз, которые гидролизуют полимер посредством поверхностной эрозии до водорастворимых мономеров и/или олигомеров, служащих субстратом для микроорганизмов. Многие микроорганизмы обладают внеклеточными ПГА-деполимеразами. Среди них бактерии (Alcaligenes faecalis, Comamonas acidovorans, Comamonas testosterone, Comamonas sp., Pseudomonas fluorescens, Pseudomonas lemoignei, Pseudomonas stutzeri, Ralstonia pickettii, Streptomyces exfoliatus) и грибы (Paecilomyces lilacinus, Penicillium funiculosum, Penicillium pinophilum) (Jendrossek, 2001). теризовано большое количество экзодеполимераз, синтезируемых прокариотами (Jendrossek and Handrick, 2002; Kim et al., 2002; Calabia and Tokiwa, 2006; Rhee et al., 2006). ПГА-экзодеполимеразом свойственны: высокая стабильность в широком диапазоне рН, температуры, ионной силы среды; относительно низкий молекулярный вес (менее 70 кДа); оптимум в щелочном диапазоне (pH 7,5-9,8). Большинство ПГАдеградирующих бактерий содержат только одну ПГА-деполимеразу. Однако встречаются виды, обладающие несколькими деполимеразами. Так, P. lemoignei кодирует 6

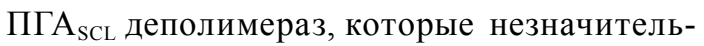
но отличаются по своим биохимическим свойствам. Comamonas sp. штамм Р37C обладает двумя отличающимися деполимеразами, гидролизующими коротко- и среднецепочечные ПГА. Присутствие двух и более 
ПЗГБ деполимераз, вероятно, усиливает эффект гидролиза этого полимера.

Свойства деполимераз изучаются в настоящее время с использованием молекулярногенетических методов. При этом большое внимание уделяется клонированию генов ПГА деполимераз. Такие исследования проведены с культурами $S$. exfoliatus K-10, $A$. faecalis, Comamonas sp., P. fluorescens GK-13, P. lemoignei, Fusarium solani (Jendrossek, 2001). Гены, контролирующие синтез бактериальных экзодеполимераз (phaZ), клонированы, в т.ч. из A. faecalis T1, Comamonas sp. DSM6781, P. lemoignei LMG2207, P. pickettii, Streptomyces sp. DSM41693, P. fluorescens GK13, DSM 7139, F. solani ATCC38136 (Jendrossek et al., 1996; Jendrossek, 2001). Группа ученых под руководством Дои (Doi et al., 1990, 1992), проводящая широкие исследования в области биосинтеза и изучения структуры и свойств различных по составу ПГА, предложила следующий механизм ферментативного гидролиза ПГА, который заключается в поверхностной эрозии и имеет двухступенчатый характер. Первая стадия - адсорбция фермента на поверхности полимера посредством связывающего сайта фермента и вторая стадия - гидролиз полимерной цепи за счет каталитического сайта фермента. Продуктами, образуемыми в ходе энзиматической деполимеризации ПГА, могут быть мономеры (например, у Comamonas sp., Alcaligenes eutrophus), димеры (P. fluorescens) или смесь олигомеров (A. faecalis и $P$. lemoignei). Олигомеры затем разрушаются до мономеров олигомерными гидролазами. Полагают, что существует два возможных места энзиматической атаки фермента при взаимодействии с упорядоченной фазой ПГА. В первом случае размер кристалла в ходе деградации уменьшается от грани по направлению к центру. Такой способ атаки может быть доступен экзоферментам, которые успешно деградируют отдельные цепи вдоль граней кристаллов полимера, начиная с доступных концов цепи. В течение всего периода деградации происходят лишь незначительные изменения молекулярного веса полимера, так как одновременно только небольшая доля от общего количества полимерных цепей в кристалле вовлечена в процесс деструкции.

Деградация ПГА может также происходить за счет разрыва полимерной С-цепи. Процесс начинается в складках С-цепей, а затем продолжается перпендикулярно ламеллярному слою до тех пор, пока не достигнет плотного ламеллярного центра, после этого процесс останавливается. Существует мнение, что отдельные кристаллы атакуются от грани кристалла предпочтительнее, чем от складки поверхности (Urmeneta et al., 1995; Hocking et al., 1996) (рис. 4). Позднее было обнаружено преобразование ПГА монокристаллов в игольчатую форму после энзиматической деградации и предложен механизм «атака граней» (Nobes et al., 1998). Вследствие адсорбции фермента на поверхности ПЗГБ монокристалла толщина фибриллярного кристалла уменьшалась от его основания по направлению к тонкому краю.

Биодеградация ПГА зависит от микроорганизмов, обитающих в данной конкретной природной среде, поэтому необходимо проведение всесторонних экологических и таксономических исследований многообразия микроорганизмов - деструкторов полимеров в различных биологических средах. Впервые микроорганизмы, разрушающие ПЗГБ, были выделены более 40 лет назад (Chowdhury, 1963). Среди них было идентифицировано несколько таксонов - Bacillus, Pseudomonas, Streptomyces. В 1965 г. были описаны еще 16 микроорганизмов, разрушающих поли-3гидроксибутират внеклеточно (Delafield et al., 1965). Далее с расширением круга исследуе- 


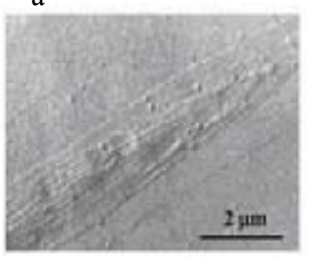

6

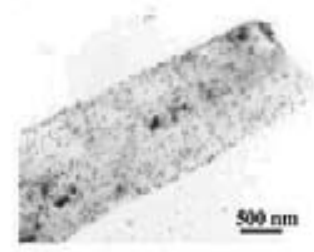

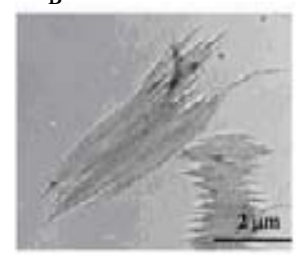

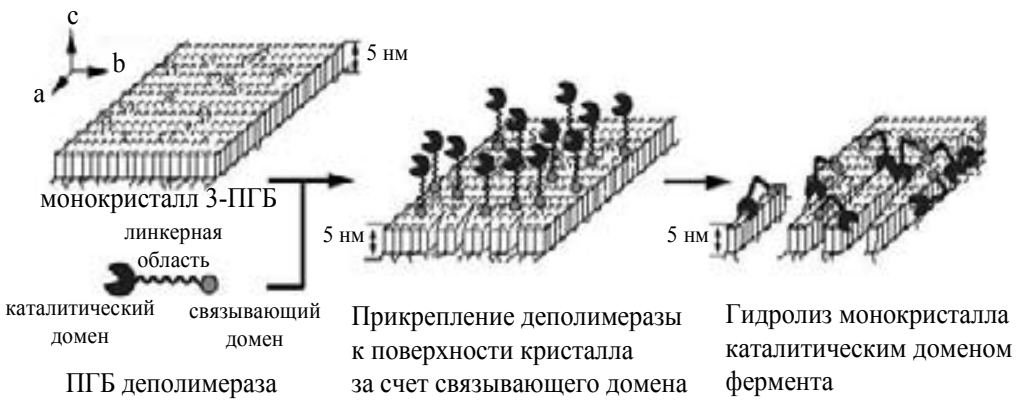

Рис. 4. Энзиматический гидролиз монокристалла поли-3-гидроксибутирата. Верхний ряд - РЭМ снимки структуры монокристалла ПЗГБ (а), связывание молекулы ПЗГБ-деполимеразы с поверхностью монокристалла ПГБ (б), энзиматический гидролиз грани монокристалла ПЗГБ (в). Нижний ряд схематическая модель стадий энзиматического гидролиза монокристалла ПЗГБ (Sudesh et al., 2000)

мых ПГА были выделены и охарактеризованы микроорганизмы, разрушающие, помимо гомогенного поли-3-гидроксибутирата, гетерополимерные коротко- и среднецепочечные полимеры (Mergeret et al., 1995). К настоящему времени, как показал анализ литературы, аэробные и анаэробные деградирующие ПГА бактерии выделены из различных экосистем, таких как почва, компост, аэробный и анаэробный ил сточных вод, пресной и морской воды, осадков эстуариев и воздуха (Imam et al., 1999; Kusaka et al., 1999; Shah et al., 2007). Очевидно, что ПГА-деградирующие микроорганизмы, в частности бактерии, разрушающие ПЗГБ, присутствуют во всех наземных и водных экосистемах.

Способностью разрушать ПГА обладают грибы. ПГА-разрушающие грибы выделены из таких биологических сред, как почва и компост (Matavulj and Molitoris, 1992), а также из пресной и морской воды, илов (Mergaert et al., 1996). В работе (Lee et al., 2005) микромицеты, способные деградировать ПЗГБ, выделены из 15 различных природных источников и, главным образом, представлены низшими грибами (Deuteromycetes). Среди деструкторов ПГА идентифицировано 95 видов микромицетов, в том числе: Ascomycetes (18), Basidiomycetes (46), Deuteromycetes (26), Mastigiomycetes (1), Myxomycetes (2), Zygomycetes (2) (Jendrossek, 2001). В серии работ последних лет исследован вклад грибов в микробную деградацию ПГА в почве. В результате скрининга штаммовдеструкторов ПЗГБ установлено, что среди изученных штаммов грибов, относящихся к родам Penicillium, Absidia, Gilbertella, Mucor, Rhizopus, более 70 \% способно утилизировать ПЗГБ (Kozlovsky et al., 1999). В ходе исследования биодеградации пленок из ПЗГБ в почве отмечено существенное увеличение численности грибной популяции на поверхности пленок, приводящее к доминированию грибов Fusarium oxysporium, Paecilomeces lilacinus и Paecilomeces farinosus (Sang et al., 2002). Вы- 
явлена преобладающая роль грибов рода Aspergillus в биодеградации ПГА (Sanyal et al., 2006) и показано, что Aspergillus sp. более активно участвует в деструкции гомополимера по сравнению с сополимером ПЗГБ/3ГВ.

Как известно, большинство ПГАдеструкторов являются мезофильными микроорганизмами и только небольшое количество термофильных видов способно к деградации при повышенных температурах. При этом выделение термофильных микроорганизмов, способных разрушать ПГА, важно для развития технологии высокотемпературного компостирования, которое признано одним из ключевых направлений при утилизации биоразрушаемых полимеров. В работах (Oda, 1995; Takeda, 1998) исследована деградация ПЗГБ при высоких температурах бактериями Leptothrix sp., Paecilomyces lilacinus. Новый термофильный микроорганизм, принадлежащий к роду Streptomyces, способный деградировать ПЗГБ, выделен из почвы (Calabia, 2004). ПЗГБ в виде пленок и порошка полностью разрушался этим организмом менее чем за 10 суток при $50{ }^{\circ} \mathrm{C}$.

В литературе имеются немногочисленные сообщения о биодеградации ПГА анаэробными микроорганизмами, хотя анаэробное усвоение биоотходов становится все в большей степени приоритетным вследствие дополнительного получения при этом биогаза. Выделены и идентифицированы анаэробные бактерии Ilyobacter delafildii, способные утилизировать полигидроксибутират, а также штаммы, относящиеся к роду Clostridium (Abou-Zeid, 2001, 2004).

Для выявления механизма деградации ПГА исследуется их разрушаемость в различных модельных средах (буферные растворы, растворы ферментов, кровь, сыворотка, культуры клеток, микрокосмы) при различных значениях рН, температуры, солености и т.д.
Для этого необходимо использовать полимеры различного химического состава, имеющие разные исходные значения молекулярной массы и кристалличности, а также полимерные изделия различной формы и структуры. Как правило, показателями деструкции ПГА служат уменьшение молекулярной массы и степени кристалличности полимера, а также изменение общего веса полимерных изделий и их прочностных свойств. В одной из ранних работ по гидролитической деградации ПГА (Doi et al., 1990) исследована разрушаемость пленок из ПЗГБ и сополимеров (ЗПГБ/ЗПГВ и ЗПГБ/4ПГБ) при экспозиции в фосфатном буфере $(\mathrm{pH} 7,4)$ при различной температуре. В течение 180 суток не было отмечено уменьшения массы образцов всех типов, однако зафиксировано снижение молекулярного веса сополимеров, особенно для ПЗГБ/4ГБ (при $70{ }^{\circ} \mathrm{C}$ практически на половину от исходного значения). В работе (Martin et al., 1999) подтверждено отсутствие химического гидролиза ПЗГБ в небиологических средах. В течение 10 недель наблюдения в фосфатном буфере при $\mathrm{pH}$ 7,4 отмечено крайне незначительное изменение молекулярной массы полимера без снижения общего веса пленок. Однако в отличие от результатов работы (Miller, Williams, 1987) в работе (Yasin, Tighe, 1992) показано, что ПГА деградируют в буферных растворах, при этом менее кристалличные сополимеры быстрее по сравнению с высококристалличным ПЗГБ, при этом динамика разрушения ПГА зависит от исходной молекулярной массы материала. Гидролитическая деградация ПГА, как правило, - медленный процесс, длящийся несколько месяцев вследствие высокой кристалличности ПГА или гидрофобной природы длинных алкильных цепей. Скорость деградации ПЗГБ увеличивается при добавлении других полимеров или пластификаторов. Так, изучение гидролитической 
деструкции пленок, изготовленных из ПЗГБ, в сравнении с пленками из смесей поли-3гидроксибутирата с тетраметилцеллюлозой (ТМЦ) при экспонировании в фосфатном буфере ( $\mathrm{pH} 7,0$ и $37^{\circ} \mathrm{C}$ ) показало, что масса пленок из ПЗГБ практически не изменялась, при этом композитные пленки деградировали (Lootz et al., 1998). Аморфные или гидрофильные добавки приводят к более высокому водопоглощению и ускоряют процесс биодеградации. Так, скорость деградации сополимера 3-гидроксибутирата с 3-гидроксивалератом с полилактидом (ПЛ) и гидрофильным полиэтиленгликолем (ПЭГ) в тетраборатном буфере $\left(\mathrm{pH} 10,37^{\circ} \mathrm{C}\right)$ в течение 7-160 суток была выше по сравнению с чистым ПЗГБ/ЗГВ (Renard et al., 2004).

Есть данные о том, что обработка полимеров ультрафиолетовым излучением значительно увеличивает скорость их деструкции (Shangguan et al., 2006). Так, после 15 недель экспозиции сополимера 3-гидроксибутирата и 3-гидроксигексаноата в физиологическом растворе пленки, обрабатываемые ультрафиолетовым излучением в течение 8 и 16 ч, сохраняли 92 и $87 \%$ от их исходного веса соответственно, тогда как необработанные ультрафиолетом образцы потеряли только 1 \% от их исходной массы. In vitro тесты показали, что добавление панкреатина в буферный раствор ускоряет деградацию ПГБ в три раза (Freier et al., 2002).

Процесс энзиматической деградации ПГА на два или три порядка выше по сравнению со скоростью простой гидролитической деградации (Kumagai et al., 1992; Kusaka, 1999). ПГАгидролизующие ферменты различаются по их субстратной специфичности к различным ПГА. Более того, физико-химические свойства самого полимера оказывают сильное влияние на его биодеградабельность. Факторы, наиболее воздействующие на биоразрушаемость, - это стереоконфигурация полимера, степень кристалличности, молекулярная масса и химический состав. Есть данные о том, что стереоконфигурация оказывает значительное влияние на процесс разрушаемости полимеpa (Abe et al., 1996; Doi et al., 1992). Все ПГАдеполимеразы специфичны для мономеров, находящихся в R-конфигурации. Синтезированные химически ПГА в S- конфигурации не разрушаются бактериальными деполимеразами. Способность к деградации ПГА уменьшается при увеличении степени кристалличности полимера (Koyama, Doi, 1997; Abe, Doi, 1999). При изучении пленочных образцов было показано, что ПГА-экзодеполимераза в первую очередь гидролизует полимерные цепи в аморфной фазе и только после этого упорядоченные зоны (Hocking et al., 1996).

Установлено, что деградация сополимеров зависит от химической структуры мономеров (Sudesh, 2000). Однако данные о влиянии состава полимера на скорость деградации весьма противоречивы. В нескольких работах показано, что сополимерные образцы ПЗГБ/ЗГВ разрушаются быстрее ПЗГБ (Madden et al., 1998; Rizzarelli et al., 2004). Однако согласно данным других авторов, разрушение ПГА бактериями Alcaligenes faecalis уменьшается в следующем порядке:

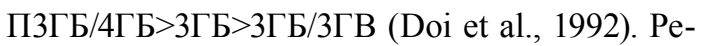
зультаты, полученные с ПГА-деполимеразами из P. lemoignei, а также in situ исследования в почве показали обратную зависимость (Kanewasa et al., 1994; Mergaert et al., 1994). Авторами было сделано предположение о том, что в природных средах различия в скоростях деградации ПГА разного типа, вероятно, происходят из-за различия деполимеризующих ферментов, выделяемых богатой микробной ассоциацией, так как известно, что деградация различных по структуре ПГА существенно зависит от специфичности активного сай- 
та в каталитической области деполимеразы (Shinomiya, 1998; Kasuya, 1999).

Следует отметить, что зачастую при выявлении деструкторов ПГА анализируют среды (почва, компост, вода), в которых экспонировали образцы полимеров и микроорганизмы, выделенные из пленок обрастания на поверхности полимеров, высевая их на стандартные микробиологические среды. При этом среди анализируемых микроорганизмов могут присутствовать организмы комменсалы, утилизирующие мономеры и другие продукты разрушения высокомолекулярных ПГА, которые появляются в среде благодаря жизнедеятельности первичных и истинных ПГА-деструкторов. Для выделения истинных деструкторов ПГА необходимо использовать метод прозрачных зон (Mergeret et al., 1993), который предусматривает высев проб на минеральный агар, содержащий в качестве единственного источника углерода ПГА. Рост на такой среде микроорганизмов, обладающих ПГА-деполимеразной активностью, сопровождается образованием вокруг колоний на поверхности агаризованной среды характерных прозрачных зон как результата разрушения полимера.

Разноречивость результатов по разрушаемости ПГА, полученных различными авторами в разное время, связана, очевидно, с тем, что для исследований были взяты образцы ПГА, синтезированные различными продуцентами на различных средах, образцы могли различаться по количеству присутствующих в них остаточных примесей (например липидной природы), способам переработки полимеров в изделия, условиями среды, в которой их экспонировали, и, наконец, авторы использовали различные методы регистрации последствий разрушения. Так, для определения степени кристалличности и молекулярной массы ПГА используют рент- геноструктурный анализ и высокоэффективную жидкостную хроматографию, но в ряде работ авторы опираются на косвенные данные, полученные с помощью ДТА или вискозиметрии.

\section{Заключение}

Выполненный анализ литературы позволяет заключить, что пока не представляется возможным прийти к единому мнению относительно закономерностей биодеградации определенных типов ПГА в конкретных биологических средах. Нет четкого ответа на вопрос о влиянии на скорость биодеградации этих полимеров таких факторов, как состав и свойства полимера, а также условий среды (температура, pH, соленость, состав микробного сообщества). С ростом объемов производства и расширением областей применения ПГА все большую актуальность приобретают исследования закономерностей процесса их разрушения в многокомпонентных и разнообразных природных условиях. Следует отметить, что результаты по разрушаемости ПГА, полученные в лаборатории, не позволяют строить прогнозные модели поведения и разрушения ПГА в сложных и изменяющихся природных экосистемах. Для этого необходимы комплексные исследования, результаты которых должны ответить на ряд ключевых вопросов:

- как состав микробиоценоза среды влияет на процесс разрушения ПГА и какие микроорганизмы являются наиболее истинными и наиболее активными деструкторами ПГА применительно к конкретным внешним условиям;

- как влияют на скорость разрушения химический состав ПГА и способ изготовления из них изделий, геометрия и размеры образцов; 
- как изменяется макро- и микроструктура ПГА и их свойства (кристалличность, молекулярная масса, полидисперсность) в процессе разрушения;

- насколько значимо влияние на этот процесс физико-химических условий среды (температура, $\mathrm{pH}$, доступность кислорода, соленость и т.п.);

- каким образом процесс разрушения ПГА будет протекать в различных регионах, различающихся погодными и климатическими условиями.

Работа выполнена за счет средств государственного задания на проведение фундаментальных исследований РАН (проект № гос. регистрации 01201351505).

\section{Список литературы}

1. Зайцев Ю. П. (2006) Введение в экологию Чёрного моря. Одесса: Эвен, 224 с. [Zaycev Y.P. (2006) Introduction in Ecology of Black sea. Odessa: Even Publishing house, 224 p.].

2. Потапов А.Г, Пармон В.Н. (2010) Биоразлагаемые полимеры-вперед в будущее. Экология и промышленность России 5: 4-8 [Potapov A.G., Parmon V.N. (2010) Biodegradable polymers forward to the future. Ecology and industry of Russia 5: 4-8].

3. Прудникова С.В., Волова Т.Г. (2012) Экологическая роль полигидроксиалканоатов - аналога синтетических пластмасс: закономерности биоразрушения в природной среде и взаимодействия с микроорганизмами. Красноярск: Красноярский писатель, 184 с. [Prudnikova S.V., Volova T.G. (2012) The ecological role of polyhydroxyalkanoates - analogue of synthetic plastics: ways of biodegradation in the environment and interaction with microorganisms. Krasnoyarsk: Krasnoyarsk writer, 184 p.].

4. Фомин В.А., Гузеев В.В. (2001) Биоразлагаемые полимеры, состояние и перспективы использования. Пластические массы 2: 42-46 [Fomin V.A., Guseev V.V. (2001) Biodegradable polymers, the status and prospects. Plastic mass 2: 42-46].

5. Abe H., Doi Y.(1996) Enzymatic and environmental degradation of racemic poly(3-hydroxybutyric acid)s with different stereoregularities. Macromolecules 29: 8683-8688.

6. Abe H., Doi Y. (1999) Structural effects on enzymatic degradabilities for poly[(R)-3hydroxybutyric acid] and its copolymers: mini rewiew. International Journal of Biological Macromolecules 25: 185-192.

7. Abou-Zeid D.M., Muller R.J., Deckwer W.D. (2001) Degradation of natural and synthetic polyesters under anaerobic conditions. Journal of Biotechnology 86: 113-126.

8. Abou-Zeid D.M., Muller R.J., Deckwer W.D. (2004) Biodegradation of alifatic homopolyesters and aliphatic-aromatic copolyesters by anaerobic microorganisms. Biomacromolecules 5: 16871697.

9. Asrar J., Gruys K.J. (2002) Biodegradable Polymer (Biopol $\left.{ }^{\circledR}\right)$. In: Steinbüchel A. (ed.) Series of Biopolymers in 10 vol, vol.4.Wiley-VCY Verlag GmbH, p.55-86.

10. Calabia B.P., Tokiwa Y. (2004) Microbial degradation of poly(D-3-hydroxybutyrate) by a new thermophilic Streptomyces isolate. Biotechnology Letters 26: 15-19.

11. Calabia B.P., Tokiwa Y. (2006) A novel PHB depolymerase from thermophilic Streptomyces sp. Biotechnology Letters 28: 383-388. 
12. Chowdhury A.A. (1963) Poly- $\beta$-hydroxybuttersäure abbauende Bakterien und Exoenzym. Archives of Microbiology 47: 167-200.

13. Delafield F.P., Doudoroff M., Palleroni N.J., Lusty C.J., Contopoulos R. (1965) Decomposition of poly- $\beta$-hydroxybutyrate by pseudomonas. Journal of Bacteriology 90: 1455-1466.

14. Doi Y., Kawaguchi Y., Koyama N., Nakamura S., Hiramitsu M., Yoshida Y. (1992) Synthesis and degradation of polyhydroxyalkanoates in Alcaligenes eutrophus. FEMS Microbiology Letters 103: 103-108.

15. Doi Y., Segawa A., Kunioka M. (1990) Biosynthesis and characterization of poly(3hydroxybutyrate-co-4-hydroxybutyrate) in Alcaligenes eutrophus. International Journal of Biological Macromolecules 12: 106-111.

16. Freier T., Kunze C., Nischan C., Kramer S., Sternberg K., Sass M., Hopt U.T., Schmitz K.P. (2002) In vitro and in vivo degradation studies for development of a biodegradable patch based on poly(3hydroxybutyrate). Biomaterials 23: 2649-2657.

17. Hocking P.J., Timmins M.R., Sherer T.M., Fuller C., Lenz R.W., Marchessault R.H. (1996) Enzymatic degradability of poly( $\beta$-hydroxybutyrate) as a function of tacticity. Journal of Macromolecular Science, Part A: Pure and Applied Chemistry 32: 889-894.

18. Imam S.H., Gordon S.H., Shogren R.L., Tosteson T.R., Govind N.S., Green R.V. (1999) Degradation of starch-poly( $\beta$-hydroxybutyrate-co- $\beta$-hydroxyvalerate) bioplastics in tropical coastal waters. Applied and Environmental Microbiology 65: 431-437.

19. Jendrossek D. (2001) Microbial degradation of polyesters. Advances in Biochemical Engineering/ Biotechnology 71: 293-325.

20. Jendrossek D., Handrick R. (2002) Microbial degradation of polyhydroxyalkanoates. Annual Review of Microbiology 56: 403-432.

21. Kanewasa Y., Tanahashi N., Doi Y. (1994) Enzymatic degradation of microbial poly(3hydroxyalkanoates). Polymer Degradation and Stability 45: 179-185.

22. Kasuya K., Ohura T., Masuda K., Doi Y. (1999) Substrate and binding specificities of bacterial polyhydroxybutyrate depolymerases. International Journal of Biological Macromolecules 24: 329-336.

23. Kijchavengkul T., Auras R. (2008) Perspective compostability of polymers. Polymer International 57: 793-804.

24. Kim D.Y., Kim H.W., Chung M.G., Rhee Y.H. (2007) Biosynthesis, modification, and biodegradation of bacterial medium-chain-length polyhydroxyalkanoates. Journal of Microbiology 45: 87-97.

25. Kim D.Y., Nam J.S., Rhee Y.H. (2002) Characterization of an extracellular medium-chainlength poly(3-hydroxyalkanoate) depolymerase from Pseudomonas alcaligenes LB19. Biomacromolecules 3: 291-296.

26. Knoll M., Hamm T.M., Wagner F. (2009) The PHA Depolymerase Engineering Database: A systematic analysis tool for the diverse family of polyhydroxyalkanoate (PHA) depolymerases. BMC Bioinformatics 10: 89-97.

27. Koyama N., Doi Y. (1997) Effects of solid-state structures on the enzymatic degradability of bacterial PHA. Macromolecules 30: 826-832.

28. Kozlovsky A.G., Zhelifonova V.P., Vinokurova N.G., Antipova T.V., Ivanushkina N.E. (1999) Study of biodegradation of poly- $\beta$-hydroxybutyrate by microscopic fungi. Microbiology 68: 289-295. 
29. Kumagai Y., Doi Y. (1992) Enzymatic degradation and morphologies of binary blends of microbial poly(3-hydroxy butyrate) with poly(e-caprolactone), poly(1,4-butylene adipate) and poly(vinyl acetate). Polymer Degradation and Stability 36: 241-248.

30. Kusaka S., Iwata T., Doi Y. (1999) Properties and biodegradability of ultra-high-molecularweight poly[(R)-3-hydroxybutyrate] produced by recombinant Escherichia coli. International Journal of Biological Macromolecules 25: 87-94.

31. Lee K.-M., Gimore D.F., Huss M.J. (2005) Fungal degradation of the bioplastic PHB (poly-3hydroxybutyric acid). Journal of Polymers and the Environment 13: 213-219.

32. Lootz D., Holbe J., Behrend D., Schmitz K.P. (1998) Comparative studies of the degradation kinetics and effect on mechanical properties of polylactide and polyhydroxybutyric acid in vitro. Biomedizinische Technik 43: 428-429.

33. Madden L., Anderson A., Asrar J. (1998) Synthesis and characterization of poly(3-hydroxybutyrate) and poly(3-hydroxybutyrate-co-3-hydroxyvalerate) polymer mixtures produced in highdensity fed-batch culture of Ralstonia eutropha (Alcaligenes eutrophus). Macromolecules 31: 5660-5667.

34. Markina Zh.V., Aizdaicher N.A. (2005) Dunaliella salina (Chlorophyta) as a test-object for assessment of detergent pollution of a marine environment. Russian Journal of Marine Biology 31 (4): 232-237.

35. Martin D.P., Skraly F.A., Williams S.F. (1999) Polyhydroxyalkanoate compositions having controlled degradation rates. PCT Patent application № WO 99/32536.

36. Matavulj N., Molitoris H. (1992) Fungal degradation of polyhydroxyalkanoates and a semiquantitative assay for screening their degradation by terrestrial fungi. FEMS Microbiology Reviews 103: 323-332.

37. Mergaert J., Anderson C., Wouters A., Swings J. (1994) Microbial degradation of poly(3hydroxybutyrate) and poly(3-hydroxybutyrate-co-3-hydroxyvalerate) in compost. Journal of Environmental Polymer Degradation 2: 177-183.

38. Mergaert J., Swings J. (1996) Biodiversity of microorganisms that degrade bacterial and synthetic polyesters. Journal of Industrial Microbiology and Biotechnology 17: 463-469.

39. Mergaert J., Webb A., Anderson C., Wouters A., Swings J. (1993) Microbial degradation of poly(3-hydroxybutyrate) and poly(3-hydroxybutyrate-co-3-hydroxyvalerate) in soils. Applied and Environmental Microbiology 59: 3233-3238.

40. Mergaert J., Wouters A., Swings J., Anderson C. (1995) In situ biodegradation of poly(3hydroxybutyrate) and poly(3- hydroxybutyrate-co-3-hydroxyvalerate) in natural waters. Canadian Journal of Microbiology 41: 154-159.

41. Miller N.D., Williams D.F. (1987) On the biodegradation of poly- $\beta$-hydroxybutyrate (PHB) homopolymer and poly- $\beta$-hydroxybutyrate-hydroxyvalerate copolymers. Biomaterials 8: 129 137.

42. Moore C., Moore S.L., Leecaster M.K., Weisberg S.B. (2001) A comparison of plastic and plankton in the North Pacific Central Gyre. Marine Pollution Bulletin 42: 1297-1300.

43. Nobes G.A.R., Marchessault R.H., Briese B.H., Jendrossek D. (1998) Microscop visualization of the enzymatic degradation of poly $(3 \mathrm{HB}-\mathrm{co}-3 \mathrm{HV})$ and poly $(3 \mathrm{HV})$ single crystals by $\mathrm{PHA}$ depolymerases from Pseudomonas lemoignei. Journal of Environmental Polymer Degradation 6: 99-107. 
44. Oda Y., Asari H., Urakami T., Tonomura K. (1995) Microbial degradation of poly(3hydroxybutyrate) and polycaprolactone by filamentous fungi. Journal of Fermentation and Bioengineering 80: 265-269.

45. Renard E., Walls M., Guérin P., Langlois V. (2004) Hydrolytic degradation of blends of polyhydroxyalkanoates and functionalized poly-hydroxyalkanoates. Polymer Degradation and Stability 85: 779-787.

46. Rhee Y.H., Kim Y.H., Shin K.S. (2006) Haracterization of an extracellular poly(3hydroxyoctanoate) depolymerase from the marine isolate, Pseudomonas luteola M13-4. Enzyme and Microbial Technology 38: 529-535.

47. Rizzarelli P., Puglisi C., Montaudo G. (2004) Soil burial and enzymatic degradation in solution of aliphatic co-polyesters. Polymer degradation and stability 85: 855-863.

48. Sang B.I., Hori K., Tanji Y., Unno H. (2002) Fungal contribution to in situ biodegradation of poly(3hydroxybutyrate-co-3-hydroxyvalerate) film in soil. Applied Microbiology and Biotechnology 58: 241-247.

49. Sanyal P., Samaddar P., Paul A. (2006) Degradation of poly(3-hydroxybutyrate) and poly(3hydroxybutyrate-co-3-hydroxyvalerate) by some soil Aspergillus spp. Journal of Polymers and the Environment 14: 257-263.

50. Scandola M., Ceccorulli G., Pizzoli M., Gazzano M. (1992) Study of the crystal phase and crystallization rate of bacterial Poly( $\beta$-hydroxybutyrate-co- $\beta$-hydroxyvalerate). Macromolecules 25: $1405-1410$.

51. Scott G. (2002) Degradable polymers. Principles and applications. Nederlands: Kluwer Academic Publ., 500 p.

52. Shah A., Hasan F., Hameed A., Ahmed S. (2007) Isolation and characterization of poly(3xydroxybutyrate-co-3-hydroxyvalerate). International biodeterioration\&biodegradation 60 : 109-115.

53. Shangguan Y.Y., Wang Y.W., Wu Q., Chen G.Q. (2006) The mechanical properties and in vitro biodegradation and biocompatibility of UV-treated poly(3-xydroxybutyrate-co-3hydroxyhexanoate). Biomaterials 27: 2349-2357.

54. Shinomiya M., Iwata T., Doi Y. (1998) The adsorbtion of substrate-binding domain of PHB depolymerases to the surface of poly(3-hydroxybutyric acid). International Journal of Biological Macromolecules 22: 129-135.

55. Stock U.A., Nagashima M., Khalil P.N., Nollert G.D., Herden T., Sperling J.S., Moran A., Lien J., Martin D.P., Schoen F.J., Vacanti J.P., Mayer J.E. Jr. (2000) Tissue-engineered valved conduits in the pulmonary circulation. Journal of Thoracic and Cardiovascular Surgery 119: $732-740$.

56. Sudesh K., Abe H., Doi Y. (2000) Synthesis, structure and properties of polyhydroxyalkanoates: biological polyesters. Progress in Polymer Science 25: 1503-1555.

57. Takeda M., Koizumi J., Yabe K., Adachi K. (1998) Thermostable poly(3-hydroxybutyrate) depolymerase of a thermophilic strain of Leptothrix sp. isolated from a hot spring. Journal of Fermentation and Bioengineering 85: 375-380.

58. UrmenetaJ.,Mas-CastellaJ.,Guerrero R.(1995)Biodegradationofpoly-(beta)-hydroxyalkanoates in a lake sediment sample in-creases bacterial sulfate reduction. Applied and Environmental Microbiology 61: 2046-2048. 
59. Volova T.G. (2004) Polyhydroxyalkanoates - Plastic Materials of the 21st Century: production, properties, application. New York: Nova Science Pub., 282 p.

60. Volova T.G., Shishatskaya E.I., Sinskey A.J. (2013) Degradable Polymers: Production, Properties and Applications. New York: Nova Science Pub., 380 p.

61. Yasin M., Tighe B.J. (1992) Polymers for medical devices: VII. Hydoxybutyrate-hydroxyvalerate copolymers: physical and degradative properties of blends with polycaprolacton. Clinical Materials 10: 21-28. 